\title{
PENINGKATAN KAPASITAS PENGELOLA RUMAH SINGGAH UNTUK ANAK JALANAN YAYASAN BINA ANAK PERTIWI
}

\author{
Maria V. Ardista ${ }^{1}$, Maria Lithania ${ }^{2}$, Anastasia Hardi ${ }^{3}$, Nikolas Priya ${ }^{4}$ \\ Gabriela Angela ${ }^{5}$, dan Clara R.P. Ajisuksmo6 \\ 1,2,3,4,5,6Fakultas Psikologi, Universitas Katolik Indonesia Atma Jaya \\ ${ }^{1}$ Email: arditsaputri@gmail.com \\ ${ }^{6}$ Email: clara.as@atmajaya.ac.id
}

\begin{abstract}
This activity is part of the final project of the Atma Jaya Faculty of Psychology Community Based Education course. In this activity students as a group conduct problems and needs assessments, and design and implement a communication capacity building program in the management of NGO organizations that provide assistance to street children. The student group consists of five people, carrying out activities at the Bina Anak Pertiwi Foundation (YBAP) an NGO that provides assistance to street children. There are two stages of activities carried out namely, the first stage is the assessment of problems and needs, and the second stage is the intervention to increase the capacity of YBAP management and staff. During the problem and needs assessment stage, interviews were conducted with four key informants and problem tree analysis. The results of the problem and needs assessment show that communication between management, staff and foster children is the main problem faced by YBAP in carrying out the program of activities to assist street children. At the intervention stage, management capacity building is carried out with a focus on communication. Capacity building was carried out through four activity sessions, namely the first "Who Am I", which aims to increase their awareness of themselves as a companion to street children. The second session "They need Us" which aims to raise awareness about who and how the characteristics they serve and assist. The third session is "Chitty chatty" which aims to improve verbal and non verbal communication skills, and the fourth session is "Broken square" which aims at increasing empathy skills and the importance of commitment to achieving common goals. The whole process of activities is carried out by participatory methods through group dynamics games, and at the end of the game there is a "debriefing" so that all participants get "insight" on the group dynamic games that are run.
\end{abstract}

Keywords: street children; program evaluation; community based education; halfway house

\begin{abstract}
ABSTRAK
Kegiatan ini merupakan bagian tugas akhir dari mata kuliah Pendidikan Berbasis Komunitas Fakultas Psikologi Unika Atma Jaya. Dalam kegiatan ini mahasiswa secara berkelompok melakukan asesmen permasalahan dan kebutuhan, serta merancang dan melaksanakan program peningkatan kapasitas komunikasi dalam manajemen organisasi LSM yang memberi pendampingan kepada anak jalanan. Kelompok mahasiswa terdiri dari lima orang, melakukan kegiatan di Yayasan Bina Anak Pertiwi (YBAP) sebuah LSM yang memberikan pendampingan kepada anak jalanan. Ada dua tahap kegiatan yang dilakukan yaitu, tahap pertama asesmen permasalahan dan kebutuhan, serta tahap kedua intervensi peningkatan kapasitas pengurus dan staff YBAP. Pada tahap asesmen permasalahan dan kebutuhan, dilakukan wawancara dengan empat orang informan kunci dan analisis pohon masalah. Hasil asesmen permasalah dan kebutuhan menunjukkan bahwa komunikasi antara pengurus, staff dan anak binaan menjadi persoalan utama yang dihadapi oleh YBAP dalam melaksanakan program kegiatan pendampingan anak jalanan. Pada tahap intervensi, dilakukan peningkatan kapasitas manajemen dengan fokus pada komunikasi. Peningkatan kapasitas dilakukan melalui empat sesi kegiatan, yaitu pertama "Siapa Saya", yang bertujuan untuk meningkatkan kesadaran mereka akan diri mereka sebagai pendamping anak jalanan. Sesi kedua "Mereka butuh Kita” yang bertujuan meningkatkan kesadaran mengenai siapa dan bagaimana karakteristik yang mereka layani dan dampingi. Sesi ketiga adalah "Chitty chatty" yang bertujuan meningkatkan keterampilan komunikasi verbal dan non verbal, dan sesi keempat adalah "Broken square" yang berujuan meningkatkan keterampilan berempati dan pentingnya komitmen untuk mencapai tujuan bersama. Seluruh proses kegiatan dilakukan dengan metode partisipatoris melalui permainan dinamika kelompok, dan di setiap akhir permainan dilakukan "debriefing” sehingga seluruh peserta memperoleh "insight” atas permainan dinamika kelompok yang dijalankan.
\end{abstract}

Kata kunci: anak jalanan; evaluasi program; pendidikan berbasis komunitas; rumah singgah 


\section{PENDAHULUAN}

Anak jalanan adalah anak yang mempertahankan kehidupan mereka dengan melakukan sebagian besar waktunya untuk beraktivitas atau berkeliaran di jalanan, di emperan toko, atau di tamantaman kota dengan mengemis, mengamen dan lainnya, guna mendapatkan upah atau sedekah. Kemiskinan orang tua adalah salah satu faktor yang mendorong anak tidak melanjutkan sekolah dan lebih banyak beraktivitas di jalanan. Faktor lain yang mendorong anak untuk berada dan hidup di jalanan adalah situasi keluarga, misalnya orang tua meninggal, kehadiran ibu tiri, perceraian orang tua, penelantaran dan perlakuan salah dari orang tua (Diriba, 2015).

Dari berbagai penelitian terdahulu, dilaporkan bahwa anak jalanan sangat rentan terhadap pelecehan seksual (Hai, 2014), perilaku seksual pra-nikah (Dwijayanti \& Herdiana, 2011; Stojadinović, Batrnek Antonić, Perinović \& Rončević, 2015), dan penggunaan narkoba (Hai, 2014; Bah, 2018). Hal ini juga berarti bahwa anak jalanan rentan terpapar oleh infeksi menular seksual (IMS) dan HIV (Setiawan, 2007). Gwanyemba, Nyamase dan George (2016) juga melaporkan bahwa anak jalanan rentan dengan perilaku kekerasan dan eksploitasi, yang pada umumnya juga dilakukan oleh sesama anak jalanan. Penelitian Stojadinović, dkk., (2015) melaporkan bahwa pada umumnya anak jalanan mempunyai pengalaman berhubungan seks pada usia 16 tahun, dan hampir separuhnya (41.2\%) melakukan hubungan seks pada usia 12 tahun. Menurut Vikasari, Suwandono dan Susanto (2016) komunitas anak jalanan identik dengan komunitas yang kurang memperhatikan hidup sehat termasuk kebersihan gigi dan mulut. Terkait dengan pemenuhan nutrisi pada anak jalanan, penelitian Prasetia, Yuliwar dan Dewi (2018) pada komunitas anak jalanan di Kota Malang menunjukkan bahwa sebagian besar (63.3\%) anak jalanan masuk dalam kategori kurang sesuai. Penelitian tersebut juga melaporkan bahwa sebanyak $46.7 \%$ anak jalanan mempunyai kadar haemoglobin dalam kategori tidak normal. Dari uraian beberapa penelitian terdahulu tersebut, ditunjukkan bahwa karena aktivitasnya di jalanan dan kurang adanya perhatian serta pendampingan dari orang tua atau orang dewasa yang lain, anak jalanan mempunyai karakteristik yang kurang memperhatikan hidup sehat, yang dapat membahayakan dirinya sendiri

Data pada tahun 2016 menunjukkan bahwa jumlah anak jalanan yang ada di Indonesia mencapai 4,1 juta (Sari \& Sumarti, 2017). Data tersebut menunjukkan bahwa upaya untuk menanggulangi masalah anak jalanan perlu dilakukan oleh berbagai pihak, baik pemerintah maupun masyarakat. Usaha pemerintah dalam melindungi hak anak tertuang dalam UU No. 35/Th. 2014, yang merupakan perubahan atas UU No. 23/Th. 2002 tentang perlindungan anak. Dalam pasal 1 UU No. 35/Th 2014 dinyatakan bahwa perlindungan anak adalah segala kegiatan untuk menjamin dan melindungi anak dan hak-haknya agar dapat hidup, tumbuh, berkembang, dan berpartisipasi secara optimal sesuai dengan harkat dan martabat kemanusiaan, serta mendapat perlindungan dari kekerasan dan diskriminasi. Selanjutnya pada pasal 25 ayat 1 Undang-Undang tersebut dinyatakan bahwa kewajiban dan tanggung jawab masyarakat terhadap perlindungan anak dilaksanakan melalui kegiatan peran masyarakat dalam penyelenggaraan perlindungan anak. Menurut Putra, Hasanah dan Nuriyah (2015) keberadaan di jalanan menjadikan anak jalanan mempunyai pengalaman hidup yang berasal dari budaya keras, dan masyarakat tidak dengan mudah menerima mereka. Oleh karena itu perlu pendampingan yang mengembangkan proses berpikir untuk membangun hubungan antara masa lalu, masa sekarang dan masa depan, serta mengarahkan mereka pada pola perikaku yang dapat diterima masyarakat. Sehubungan dengan pernyataan tersebut, maka lembaga swadaya masyarakat, yayasan sosial dan rumah singgah, mempunyai peranan penting dalam memberikan perubahan yang signifikan terhadap keberadaan anak jalanan (Sari \& Sumarti, 2017). 
Salah satu rumah singgah yang melakukan pendampingan kepada anak jalanan, dan mengelola rumah singgah untuk anak jalanan adalah Yayasan Bina Anak Pertiwi (YBAP). YBAP adalah lembaga swadaya masyarakat (LSM) yang berlokasi di Pasar Minggu Jakarta Selatan. YBAP merupakan pusat pembinaan dan rumah belajar anak jalanan dan anak terlantar, yang menjalankan kegiatannya bersama-sama masyarakat yang ada di sekitar. YBAP didirikan secara khusus untuk turut serta memberikan pelayanan sosial kepada anak yatim, anak jalanan atau terlantar, dan anak kurang mampu. YBAP juga membantu anak-anak tersebut mengatasi permasalahan hidup, dengan memberikan bekal pendidikan, pembinaan sikap mental positif, serta keterampilan kerja untuk menuju kemandirian.

Visi dari YBAP adalah meningkatkan taraf hidup serta kesejahteraan sosial masyarakat fakir miskin, terutama anak yatim, anak jalanan/terlantar serta anak kurang mampu menjadi anak bangsa yang konstruktif dan bermartabat sejalan dengan potensi yang dimilikinya untuk mewujudkan masa depan bangsa yang lebih berkualitas. Misi YBAP adalah 1) Menumbuhkan rasa percaya diri yang tinggi; 2) Menciptakan peluang kerja baru dengan mengembangkan pelatihan kerja; 3) Menggali serta memberdayakan potensi yang dimilikinya agar menjadi manusia yang mandiri dan produktif; dan 4) Mengembangkan peran serta masyarakat dan pihak-pihak terkait untuk turut serta mengentaskan dan memberdayakan fakir miskin, terutama anak yatim, anak jalanan /terlantar, dan anak kurang mampu. Tujuan Program YBAP adalah, a) Mengembangkan sikap mental positif; b) Membangun Akhlak al-Karimah; c) Menggali serta memberdayakan potensi yang dimiliki warga belajar; dan d) Memberikan gambaran akan kepastian masa depan dengan berbekal berbagai keterampilan kerja dan pengembangan usaha mandiri, serta penempatan kerja.

Dari visi, misi dan tujuan program, YBAP mengembangkan enam program kegiatan untuk anakanak yang ada di bawah pendampingan mereka. Keenam program kegiatan tersebut adalah pertama bimbingan agama dan etika bermasyarakat. Program ini dimaksudkan untuk membangun sikap mental positif dan menumbuhkan kembali semangat keberagaman anak. Kedua, pendidikan dan pelatihan keterampilan. Kegiatan ini diadakan dalam rangka mengembalikan anak didik ke dalam suasana belajar. Termasuk di dalamnya adalah pendidikan luar sekolah (Kejar Paket A dan Paket B), serta menyekolahkan anak ke sekolah formal bagi anak yang memiliki minat dan masih memungkinkan diterima di sekolah umum, serta pelatihan keterampilan dan penempatan kerja diberikan dengan maksud membekali anak dengan berbagai keterampilan yang berorientasi kerja. Ketiga, pengembangan minat dan bakat (seni budaya). Kegiatan ini difokuskan untuk menggali bakat seni yang ada dalam diri anak. Keempat, program kesejahteraan dan pelayanan kesehatan. Program ini ditekankan untuk meningkatkan kesejahteraan serta pelayanan kesehatan anak. Kelima, program pengembangan usaha mandiri. Program ini dimaksudkan untuk membuka lapangan kerja baru. Keenam, program aksi sosial kemanusiaan yang ditujukan untuk meningkatkan rasa peduli dengan meringankan masyarakat yang sedang tertimpa musibah.

Kepengurusan dan pendampingan para pengajar di YBAP bersifat sukarela sebagai relawan yang tidak mendapat gaji tetap yang diberikan setiap bulan. Relawan merupakan cikal bakal dan bentuk sederhana dari pekerja sosial (Arliani, Sulastri, \& Taftazani, 2015). Pekerja sosial merupakan bidang keahlian yang memiliki kewenangan untuk melaksanakan berbagai upaya, guna meningkatkan kemampuan individu dalam melakukan tugas dan fungsi sosialnya (Arliani, Sulastri, \& Taftazani, 2015). Para pekerja sosial dipandang mampu untuk memanipulasi perilaku manusia. Dalam konteks rumah singgah, relawan dan pekerja sosial melakukan intervensi dan membina anak jalanan supaya tidak berkeliaran mencari kehidupan di jalanan, dan termotivasi untuk bersekolah dan mengejar cita-cita. Sebagian besar dari para pengurus dan pengajar YBAP adalah masyarakat yang ada di sekitar YBAP atau mantan anak jalanan. Secara keseluruhan YBAP 
memiliki pengurus dan pengajar yaitu pengajar mata pelajaran Bahasa Indonesia, Matematika, Mengaji dan Karate, sebanyak 19 orang.

Menurut Sari dan Sumarti (2017) untuk mengukur efektivitas rumah singgah yang ditujukan untuk pemberdayaan anak jalanan harus ditinjau dari perspektif anak jalanan, karena mereka adalah penerima program. Dari laporan Undugu Society of Kenya (2010) dalam mengevaluasi program untuk anak jalanan, masing-masing anak yang menerima program harus dipandang sebagai individu yang mempunyai karakteristik unik, dan bukan dipandang sebagai suatu kelompok anak jalanan yang mempunyai karakteristik "jalanan". Anak jalanan sebagaimana anak lain yang hidup dalam keluarga berkembang dan tumbuh dengan langkah keunikannya sendiri meskipun kehidupannya sebagai kelompok anak jalanan ikut mempengaruhi.

YBAP sebagai lembaga swadaya masyarakat (LSM) merupakan bagian dari masyarakat sipil yang mengorganisasikan diri untuk meningkatkan kesejahteraan anak-anak yang kurang beruntung. LSM memiliki struktur kelembagaan, mengandalkan pada staf baik yang dibayar maupun yang relawan, memiliki dasar keuangan yang mínimum dan berfokus pada melayani sesama lewat pelayanan langsung (Lassa \& Li, 2015). Menurut Putra (2006), ada beberapa persoalan terkait dengan efektifitas LSM, dan salah satunya adalah kecakapan manajemen dan organisasi. Menurut Putra (2006) kebanyakan LSM tidak memiliki manajemen organisasi yang jelas dan tidak mengacu pada prinsip manajemen moderen. Sebagai akibatnya, manajemen organisasi LSM lebih sering terfokus pada satu aktor dan mengabaikan misi yang diperjuangkan.-Manajemen berkaitan dengan seluruh usaha dan aktivitas individu dalam organisasi untuk mencapai tujuan secara efektif. Pengelolaan manajemen yang baik akan berdampak pada tingkat efektivitas di organisasi tersebut (Rifa'i dan Fadhli, 2013).-Manajemen dalam organisasi terdiri dari beberapa aspek penting, di antaranya adalah kepemimpinan, komunikasi, dan motivasi. Dalam konteks permasalahan yang dialami YBAP, manajemen komunikasi organisasi menjadi aspek yang menurut mereka mendasari konflik yang terjadi di dalam organisasi. Dengan mengacu dari uraian yang telah dijelaskan di atas, maka kegiatan dilakukan dengan menganalisis terhadap permasalahan dan kebutuhan peningkatan kapasitas, serta dilakukan program intervensi untuk meningkatkan kapasitas manajemen organisasi dari YBAP.

\section{METODE PELAKSANAAN}

Fokus kegiatan ini adalah peningkatan kapasitas manajemen orgaisasi YBAP. Kegiatan ini dilakukan di Rumah Singgah Yayasan Bakti Anak Pertiwi (YBAP), yang merupakan rumah singgah untuk anak jalanan dan berlokasi di Pasar Minggu Jakarta Selatan. Partisipan kegiatan adalah pengurus dan staf YBAP, sebanyak 7 orang. Kegiatan dilakukan dalam dua tahap, yaitu: 1) tahap asesmen permasalahan, dan 2) tahap intervensi peningkatan kapasitas organisasi.

Pada awal dan akhir intervensi dilakukan pre-test dan post test terkait pengetahuan peserta mengenai komunikasi. Ada 10 soal pertanyaan yang mengacu pada teori komunikasi asertif, contoh pertanyaan ada pada Tabel 1 .

Tahap 1: Asesmen Permasalahan.

Asesmen permasalahan dilakukan dengan dua metode, yaitu metode wawancara informan kunci dan metode analisis pohon masalah.

\section{a. Wawancara Informan Kunci}

Wawancara dilakukan untuk memperoleh informasi terkait hambatan dan masalah yang dihadapi oleh YBAP dalam mengelola rumah singgah untuk anak jalanan. Wawancara dilakukan dengan 4 
orang informan kunci, yaitu pimpinan yayasan, pengurus yayasan dan dua anak binaan yang tinggal di rumah singgah. Pemimpin yayasan berjenis kelamin laki-laki dan berusia 38 tahun. Pengurus yayasan berjenis kelamin perempuan, berusia 20 tahun dan merupakan mahasiswa jurusan Bimbingan Konseling dari sebuah perguruan tinggi di Jakarta. Dua anak laki-laki yang merupakan binaan dari YBAP berusia 16 tahun dan tinggal di rumah singgah tersebut.

Tabel 1. Contoh soal pre-test dan post test

\begin{tabular}{|c|c|c|}
\hline No & Soal & Jawaban \\
\hline 1 & $\begin{array}{l}\text { Setiap kali melakukan presentasi di depan kelas, } \\
\text { Ardi menunjukkan sikap tubuh yang agak } \\
\text { membungkuk dan terkesan tidak percaya diri. Hal } \\
\text { ini membuat teman-teman sekeleasnya tidak ada } \\
\text { yang memerhatikan ketika Atdi berdiri di depan } \\
\text { kelas untuk mempresentasikan tugasnya }\end{array}$ & $\begin{array}{l}\text { Jenis komunikasi non-verbal yang tidak diterapkan } \\
\text { oleh Ardi adalah } \\
\text { a. Tone of voice } \\
\text { b. Stance } \\
\text { c. Facial expression } \\
\text { d. Eye contact }\end{array}$ \\
\hline 2 & $\begin{array}{l}\text { Dalam berkomunikasi penting untuk menyesuaikan } \\
\text { lembut atau kerasnya suara kitasaat menyampaikan } \\
\text { suatu pesan atau informasi kepada orang lain }\end{array}$ & $\begin{array}{l}\text { Jenis komunikasi non-verbal yang dimaksud adalah } \\
\text { a. Tone of voice } \\
\text { b. Stance } \\
\text { c. Facial expression } \\
\text { d. Eye contact }\end{array}$ \\
\hline
\end{tabular}

Pertanyaan kunci untuk pimpinan YBAP (Tabel 2) adalah mengenai rumah singgah termasuk kegiatan sehari-hari di rumah singgah dan perkembangan rumah singgah dari waktu ke waktu. Pertanyaan untuk pengurus rumah singgah adalah hambatan yang dialami oleh pengurus dalam mengelola rumah singgah. Informasi yang digali dari anak binaan rumah singgah adalah bagaimana kehidupan sehari-hari di rumah singgah dan bagaimana pengelolaan rumah singgah dari perspektif anak binaan. Informasi dari anak binaan bisa dikatakan sebagai triangulasi dari informasi yang diberikan oleh pimpinan dan pengurus rumah singgah

Tabel 2. Contoh pertanyaan dalam asesmen kebutuhan

\begin{tabular}{|c|c|}
\hline Tujuan & Pertanyaan \\
\hline $\begin{array}{l}\text { 1. Mengidentifikasi masalah yang sering dihadapi di } \\
\text { rumah singgah. } \\
\text { 2. Mengetahui cara pimpinan dan pengurus rumah } \\
\text { singgah dalam mengatasi permasalahan yang } \\
\text { dihadapi oleh rumah singgah } \\
\text { 3. Mengetahui apa yng dibutuhkan untuk } \\
\text { memecahkan masalah yang dihadapi oleh YBAP }\end{array}$ & $\begin{array}{l}\text { 1. Masalah apa yang umumnya dihadapi oleh YBAP? } \\
\text { 2. Masalah tersebut terjadi di pihak mana? Yayasan? } \\
\text { Pengurus? Staff pendamping anak binaan? Anak } \\
\text { Binaan? } \\
\text { 3. Bagaimana mengatasi masalah tersebut? } \\
\text { 4. Apakah cara untuk mengatasi masalah memberikan } \\
\text { hasil? } \\
\text { 5. Apabila ada pihak lain yang membantu manajemen } \\
\text { organisasi YBAP, di bidang/area apa sebaiknya }\end{array}$ \\
\hline
\end{tabular}

\section{b. Analisis Pohon Masalah}

Salah satu kegiatan yang dilakukan untuk asesmen kebutuhan adalah dengan melakukan analisis pohon masalah. Analisis pohon masalah ditujukan untuk mengidentifikasi masalah dan hubungan sebab akibat, serta faktor yang saling terkait dalam manajemen organisasi YBAP. Analisis pohon masalah juga dapat digunakan untuk merencanakan program yang akan dilakukan. Dari hasil pemetaan hubungan sebab akibat dan analisis pohon masalah dapat ditemukan pemecahan masalah yang lebih terstruktur. Selain itu, dengan melakukan analisis pohon masalah maka organisasi juga dapat lebih mudah menyusun langkah-langkah rencana pemecahan masalah. Dalam melakukan analisis pohon masalah dilakukan curah pendapat dari para pengurus YBAP. Peserta yang mengikuti kegiatan analisis Pohon Masalah ada 7 orang yang merupakan gabungan antara pengurus Yayasan dan Relawan pendamping anak 
Berikut ini adalah langkah-langkah yang dilakukan dalam analisis pohon masalah dengan pengurus dan relawan YBAP:

1. Peserta diberi lembaran karton meta plan, dan diminta mengidentifikasi masalah inti dalam manajemen organisasi YBAP dengan menuliskan masalah tersebut di lembar karton meta plan

2. Peserta diminta untuk memformulasi masalah inti menjadi isu utama dengan membuat pernyataan dalam kalimat pendek

3. Peserta diminta untuk meletakkan pernyataan masalah di posisi yang paling atas dari pohon masalah

4. Peserta diminta untuk membuat hubungan sebab akibat, dengan meletakkan penyebab di bagian bawah dan akibat di bagian atas

5. Peserta diminta mereview dan memverifikasi pohon masalah yang dibuat

Tahap 2: Intervensi Program Peningkatan Kapasitas

Mengacu pada hasil analisis masalah yang dilaksanakan dua minggu sebelumnya, maka dilakukan intervensi peningkatan kapasitas berorganisasi pada pengurus dan pendamping anak di YBAP dengan fokus pada keterampilan berkomunikasi antar anggota organisasi. Kegiatan intervensi (Tabel 3) ini dilakukan dalam empat sesi yaitu: 1) Siapakah Aku; 2) Mereka Butuh Kita; 3) Chitty Chatty, 4) Melipat dan merobek kertas, dan 5) Broken square. Pada tabel di bawah ini dijelaskan sesi kegiaan intervensi, tujuan yang hendak dicapai dari kegiatan tersebut, aktivitas yang dilakukan dan prosedur yang dilakukan untuk melaksanakan aktivitas tersebut.

Tabel 3. Sesi intervensi peningkatan kapasitas

\begin{tabular}{|c|c|c|c|c|}
\hline No & Sesi & Tujuan & Aktivitas & Prosedur \\
\hline 1 & $\begin{array}{l}\text { Siapakah } \\
\mathrm{Aku}\end{array}$ & $\begin{array}{l}\text { Menyamakan } \\
\text { persepsi para peserta } \\
\text { mengenai peran } \\
\text { mereka yaitu sebagai } \\
\text { pengurus, relawan } \\
\text { pendamping anak di } \\
\text { YBAP }\end{array}$ & $\begin{array}{l}\text { Permainan } \\
\text { "Apa yang } \\
\text { Harus Saya } \\
\text { Lakukan?" }\end{array}$ & $\begin{array}{l}\text { Peserta dibagi ke dalam dua kelompok (Peserta } 7 \\
\text { orang) yang masing-masing akan diberikan sembilan } \\
\text { kartu berisi kasus di Yayasan Bina Anak Pertiwi. } \\
\text { Kasus diperoleh dari proses diskusi dan analisis } \\
\text { masalah. Peserta diminta mendiskusikan respon dan } \\
\text { tindakan yang dilakukan untuk mengatasi masalah } \\
\text { tersebut. Pada akhir kegiatan, dilakukan debriefing }\end{array}$ \\
\hline 2 & $\begin{array}{l}\text { Mereka } \\
\text { Butuh } \\
\text { Kita }\end{array}$ & $\begin{array}{l}\text { Memiliki persepsi } \\
\text { yang sama tentang } \\
\text { anak yang dibina dan } \\
\text { peran mereka }\end{array}$ & $\begin{array}{l}\text { Diskusi } \\
\text { Kelompok }\end{array}$ & $\begin{array}{l}\text { Peserta menulis di kertas meta plan mengenai } \\
\text { karakteristik anak yang mereka bina/dampingi dan } \\
\text { apa arti anak binaan bagi mereka. Pada akhir } \\
\text { kegiatan diskusi kelompok, peserta diajak untuk } \\
\text { menarik kesimpulan mengenai hal-hal yang } \\
\text { diharapkan dari para pendamping anak dengan } \\
\text { mengacu pada karakterisitk anak yang mereka } \\
\text { dampingi. }\end{array}$ \\
\hline 3 & $\begin{array}{l}\text { Chitty } \\
\text { Chatty }\end{array}$ & $\begin{array}{l}\text { Meningkatkan } \\
\text { pemahaman peserta } \\
\text { akan bentuk-bentuk } \\
\text { komunikasi (verbal } \\
\text { dan non-verbal) }\end{array}$ & $\begin{array}{l}\text { Permainan } \\
\text { "Chitty } \\
\text { Chatty". }\end{array}$ & $\begin{array}{l}\text { - Pada permainan chitty chatty, peserta diminta } \\
\text { untuk berpasangan, setiap pasangan, akan } \\
\text { diberikan nama orang } 1 \text { dan orang } 2 \text {. Orang } 1 \text { akan } \\
\text { diberikan } 1 \text { dari } 5 \text { peran, yaitu 1) selalu memotong } \\
\text { pembicaraan lawan bicara; 2) arah mata tidak } \\
\text { memandang ke arah lawan bicara; } 3 \text { ) berbicara } \\
\text { dengan suara yang keras; 4) selalu menundukkan } \\
\text { kepala saat berbicara, dan 5) mencondongkan } \\
\text { badan sedekat-dekatnnya dengan lawan bicara. } \\
\text { Orang } 2 \text { akan menjadi lawan bicara tanpa tahu } \\
\text { peran yang dilakukan oleh orang } 1 \text {. } \\
\text { - Orang } 2 \text { kemudian diminta untuk mengungkapkan } \\
\text { perasaan mereka apabila mereka berkomunikasi } \\
\text { dalam situasi yang dilakukan oleh pasangan } \\
\text { mereka }\end{array}$ \\
\hline
\end{tabular}




\begin{tabular}{|c|c|c|c|c|}
\hline & & & & $\begin{array}{l}\text { - Pada akhir kegiatan dilakukan debriefing terkait } \\
\text { bentuk-bentuk komunikasi dan reaksi dalam } \\
\text { komunikasi. Apakah mereka nyaman bila lawan } \\
\text { bicara mereka menunjukkan perilaku seperti } \\
\text { dalam permainan tsb. }\end{array}$ \\
\hline 4 & $\begin{array}{l}\text { Melipat } \\
\text { dan } \\
\text { Merobek } \\
\text { Kertas }\end{array}$ & $\begin{array}{l}\text { Meningkatkan } \\
\text { pemhaman peserta } \\
\text { akan pentingnya } \\
\text { komunikasi dua arah }\end{array}$ & $\begin{array}{l}\text { Permainanan } \\
\text { melipat kertas }\end{array}$ & $\begin{array}{l}\text { - Pada permainan melipat kertas, dilakukan dua } \\
\text { sesi, yaitu 1) tanpa umpan balik dan 2) dengan } \\
\text { umpan balik. } \\
\text { - Pada sesi 1, peserta diberi kertas, dan diminta } \\
\text { melipat dan menyobek kertas (beberapa kali } \\
\text { lipatan dan beberapa kali sobekan). Peserta tidak } \\
\text { boleh bertanya atau berkomentar. Mereka diminta } \\
\text { hanya mengikuti instruksi dari fasilitator. Setelah } \\
\text { selesai dengan beberapa lipatan dan sobekan, } \\
\text { peserta diminta untuk membuka lembaran kerts } \\
\text { dan melihat hasilnya. Dari lipatan dan sobekan } \\
\text { peserta menunjukkan hasil yang berbeda. } \\
\text { - Pada sesi 2, dilakukan hal yang sama dengan sesi } \\
\text { 1, namun pada sesi } 2 \text { ini seluruh peserta boleh } \\
\text { bertanya mengenai detil dari melipat dan merobek } \\
\text { kertas (ada umpan balik). Dari melipat dan } \\
\text { merobek kertas yang memberi kesempatan } \\
\text { bertanya, ditunjukkan hasil yang sama meski ada } \\
\text { sedikit perbedaan. } \\
\text { - Pada akhir kegiatan dilakukan debriefing } \\
\text { mengenai komunikasi dua arah }\end{array}$ \\
\hline 5 & $\begin{array}{l}\text { Broken } \\
\text { Square }\end{array}$ & $\begin{array}{l}\text { Meningkatkan } \\
\text { keterampilan } \\
\text { berempati dan } \\
\text { berkomunikasi } \\
\text { secara asertif }\end{array}$ & $\begin{array}{l}\text { Permainan } \\
\text { Broken Square }\end{array}$ & $\begin{array}{l}\text { - Peserta dibagi menjadi dua kelompok dan setiap } \\
\text { kelompok terdiri dari } 5 \text { orang (peserta dari YBAP } \\
\text { hanya } 7 \text { orang sehingga } 3 \text { orang fasilitator ikut } \\
\text { serta dalam permainan ini). } \\
\text { - Setiap kelompok menerima } 5 \text { amplop yang berisi } \\
\text { potongan dari bujur sangkar. Tugas masing- } \\
\text { masing kelompok adalah menghasilkan lima bujur } \\
\text { sangkar yang dibuat oleh masing-masing anggota } \\
\text { kelompok. Dalam membuat bujur sangar tsb, ada } \\
\text { aturan ysitu a) tidak boleh berbicara, b) tidak } \\
\text { boleh meminta dan hanya boleh memberi } \\
\text { potongan bujur sangkar } \\
\text { - Selesai permainan dilakukan debriefing mengenai, } \\
\text { empati, asertif, kecemasan dalam menghadapi } \\
\text { aturan mengenai komunikasi, dan ada } \\
\text { kecenderungan untuk melanggar aturan. }\end{array}$ \\
\hline
\end{tabular}

\section{HASIL DAN PEMBAHASAN}

a. Permasalahan YBAP

Gambar 1, menunjukkan hasil wawancara dengan informan kunci dan analisis pohon masalah di YBAP. Komunikasi yang buruk di antara pengurus dan antara pengurus dengan anak binaan muncul sebagai masalah utama dari efektifitas penyelanggaraan program di YBAP.

Berdasarkan Gambar 1. ditunjukkan bahwa komunikasi yang buruk berdampak pada proses binaan anak-anak di YBAP, disebabkan oleh beberapa faktor, yaitu:

1. Pengurus mengharapkan imbalan dari kegiatan yang dilakukan oleh YBAP

2. Pengurus memendam masalah yang dihadapi

3. Ada persoalan yang belum terselesaikan antara pengurus dan yayasan

4. Pengurus tidak saling percaya. 
Dengan komunikasi yang buruk tersebut berakibat pada timbulnya kecemburuan antar pengurus dan saling menjelekkan satu sama lain. Hal ini berakibat pada ketidak kompakkan para pengurus sehingga mereka salah dalam membimbing anak-anak dampingan mereka dan anak-anak binaan menjadi merasa paling benar serta sulit diatur.

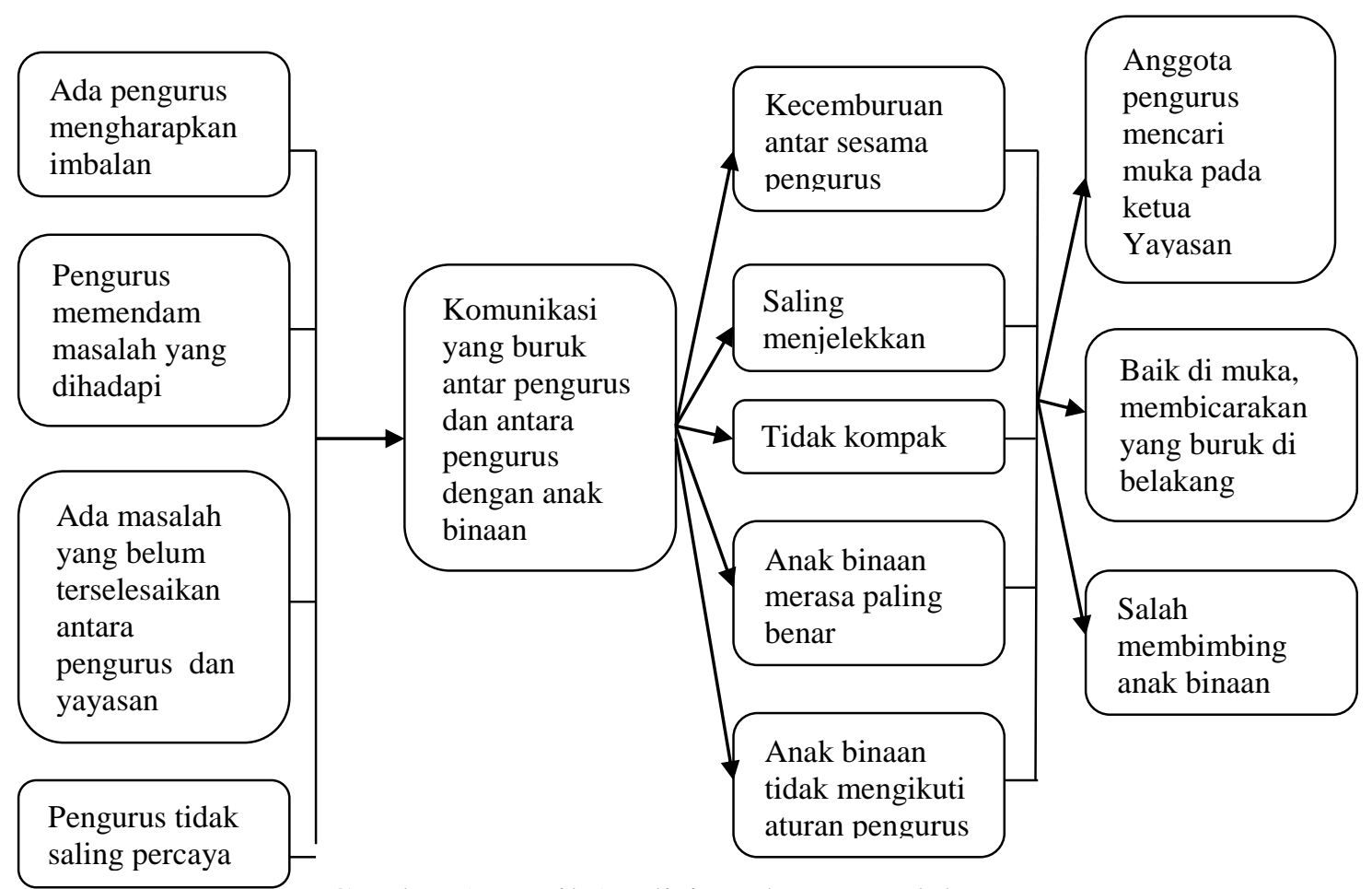

Gambar 1. Hasil Analisis Pohon Masalah

Tabel 4. Hasil pre-test dan post-test

\begin{tabular}{|c|c|c|c|}
\hline No. & Insial Nama & Pre-test & Post-test \\
\hline 1. & A & 3 & 3 \\
\hline 2. & SS & 6 & 8 \\
\hline 3. & MR & 4 & 5 \\
\hline 4. & A2 & 2 & 6 \\
\hline 5. & DJ & 6 & 7 \\
\hline 6. & IM & 3 & 4 \\
\hline 7. & AA & 7 & 10 \\
\hline
\end{tabular}

b. Hasil Evaluasi Pengetahuan mengenai Komunikasi

Tabel 4, menunjukkan hasil pre-test dan post-test pemahaman peserta mengenai komunikasi. Dari tabel di bawah ditunjukkan bahwa 6 dari 7 orang peserta meningkat pengetahuan mereka terkait komunikasi. Ada 2 orang peserta yang menunjukkan peningkatan lebih dari dua skor, yaitu AA dan A2 yang meningkat 3 sampai 4 skor. Tidak diperoleh alasan mengapa ada yang meningkat dengan tinggi, dan ada yang tidak meningkat. 


\section{KESIMPULAN DAN SARAN}

Berdasarkan kegiatan analisis masalah di YBAP diperoleh informasi bahwa komunikasi antar anggota organisasi merupakan persoalan utama dari YBAP. Komunikasi yang tidak cukup baik disebabkan oleh beberapa hal yaitu, ada pengurus yang mengharapkan imbalan dari kegiatan yang dilakukan oleh YBAP, ada pengurus memendam masalah yang dihadapi, ada persoalan yang belum terselesaikan antara pengurus dan yayasan, dan pengurus tidak saling percaya. Komunikasi yang buruk berdampak pada timbulnya kecemburuan antar pengurus dan saling menjelekkan satu sama lain. Hal ini berakibat pada ketidak kompakkan para pengurus sehingga mereka salah dalam membimbing anak-anak dampingan mereka dan anak-anak binaan menjadi merasa paling benar serta sulit diatur.

Berdasarkan kegiatan ini, ada beberapa saran yang diajukan oleh peserta terkait pelaksanaan intervensi peningkatan kapasitas, yaitu

1. Waktu yang diberikan terlalu pendek, yaitu hanya 90 menit sehingga pelaksanaan kegiatan tidak maksimal.

2. Akan menarik bila diberikan juga film terkait dengan komunikasi asertif dalam berorganisasi. Dengan melihat film dan mendiskusikan isi film tersebut, diharapkan peserta dapat lebih mudah memahami materi mengenai bagaimana seharusnya komunikasi dilakukan, mengapa komunikasi dapat terhambat, bagaimana komunikasi dapat dilakukan termasuk di dalamnya komunikasi verbal, komunikasi non-verbal, komunikasi satu arah, komunikasi dua arah, empati dan kecemasan dalam berkomunikasi, komunikasi asertif dan lainnya.

3. Dalam melakukan intervensi peningkatan kapasitas, penting bagi fasilitator untuk menerapkan berbagai pendekatan atau metode yang menarik dan membantu meningkatkan pengetahuan serta keterampilan peserta.

\section{Ucapan Terima Kasih}

Terimakasih disapaikan kepada pimpinan, pengurus, relawan dan anak-anak dampingan Rumah Singgah Yayasan Bina Anak Pertiwi atas informasi yang sangat berharga dan waktu yang diberikan untuk berpartisipasi dalam penelitian ini.

\section{REFERENSI}

Arliani, P. N. A., Sulastri, S., \& Taftazani, B. M. (2015). Penerapan pengetahuan dan keterampilan pekerja sosial oleh relawan dalam pendampingan kepada anak penderita kanker. Prosiding Penelitian dan Pengabdian kepada Masyarakat, 2(1). http://jurnal.unpad.ac.id/prosiding/article/view/13268

Badan Pusat Statistik. (2018). Profil Kemiskinan di Indonesia Maret 2018. Berita Resmi Statistik No.57/07/Th. XXI, 16 Juli 2018.

Bah, Y.M. (2018). Drug abuse among street children. Mathews Journal of Case Reports, 3(1): 038.

Dalimunthe, S. F. (2016). Manajemen konflik dalam organisasi. Jurnal Bahas Unimed, 27(1).

Dewi, R. L., \& Kartowagiran, B. (2018). An evaluation of internship program by using Kirkpatrick evaluation model. Research and Evaluation in Education, 4(2): 155-163.

Diriba, T. (2015). Family problem as a contributing factor for street children. The Case of Nekemte Town. International Journal of Research and Scientific Inovation, 2(9); 137-144

Dimitrov, D. M., \& Rumrill, P. D. (2003). Pretest-posttest designs and measurement of change. Speaking of Research, 20(2): 159-165.

Dwijayanti, Y. R. \& Herdiana, I. (2011) Perilaku seksual anak jalanan ditinjau dengan teori 
health belief model (HBM). Insan. Media Psikolopgi, 13(2): 129-1372016 ISSN: 24541362,http://www.onlinejournal.inImperial Journal of Interdisciplinary Research (IJIR) Page 60

Gwanyemba, J., Nyamase, E. \& George, B. (2016). Resilience of street children to violence, exploitation and abuse in Tanzanian cities: Evidence from Unga Limited Ward in Arusha City. Imperial Journal of Interdisciplinary Research (IJIR), 2 (7): 60-65

Hai, M.A. (2014). Problems faced by the street children: a study on some selected places in Dhaka City, Bangladesh. International Journal of Scientific \& Technology Research, 3 (10): 4556.

Hidayat, R. (2013). Pengaruh kepemimpinan terhadap komunikasi, kepuasan kerja, dan komitmen organisasi pada industri perbankan. Makara Seri Sosial Humaniora, 17(1): 19-32.

Lassa, J. \& Li, D.E. (2015). Jaringan LSM dan masa depan keberlanjutan LSM di Indonesia. Knowledge Sector Inisiative. Cardno

Miyarso, E. (2007). Manajemen konflik mahasiswa sebagai metode pembelajaran alternatif. Majalah Ilmiah Pembelajaran, 3(2).

Prasetia, A., Yuliwar, R. \& Dewi, N. (2018). Hubungan pola pemenuhan nutrisi dengan kadar hemoglobin pada anak jalanan di Kota Malang, Nursing News: Jurnal Ilmiah Keperawatan, $3(1): 108-119$.

Putra, E.V. (2006). Laporan Penelitian Peningkatan Kapasitas Organisasi Masyarakat Sipil Dalam Penerapan Transparansi dan Akuntabilitas Studi Kasus: Konsorsium Pengembangan Masyarakat Madani (KPMM). Jurusan Sejarah Fakultas Ilmu-Ilmu Sosial. Universitas Negeri Padang.

Putra, F., Hasanah, D. \& Nuriyah, E. (2015). Pemberdayaan anak jalanan di rumah singgah. Share Social Work Jurnal, 5(1): 51-64

Sari, D. dan Sumarti, T. (2017). Analisis efektivitas program pemberdayaan anak jalanan di rumah singgah Tabayun Kecamatan Cibinong, Kabupaten Bogor. Jurnal Sains Komunikasi dan Pengembangan masyarakat, 1(1): 29-42.

Setiawan, H.H. (2007). Pemberdayaan anak jalanan melalui program Score dalam mencegah penyebaran HIV/AIDS. Jurnal Penelitian dan Pengembangan Kesejahteraan Sosial, 12 (3): 23-32

Sriwartini, Y. dan Kartikawati, D. (2015). Manajemen komunikasi pengelola rumah singgah dalam proses pra dan masa pembinaan anak-anak jalanan. Jurnal Ilmu dan Budaya, 39 (45).

Stojadinović, A., Batrnek Antonić, D., Perinović, M., \& Rončević, N. (2015). Sexual behavior of street children, Medicinski Pregled, LXVIII (7-8): 245-250.

Undugu Society of Kenya (2010). Evaluation of the children and youth programme: Final Report. Pan African Research Services. Nairobi, Kenya

Komisi Perlindungan Anak Indonesia. (2014). Undang-undang Republik Indonesia Nomor 35 Tahun 2014 Tentang Perubahan Undang-undang Nomor 23 Tahun 2002 Tentang Perlindungan Anak.

Vikasari, A. Suwandono, A., Susanto, H.S. (2016). Gambaran faktor risiko penyakit periodontal pada anak jalanan dengan eks anak jalanan di Kota Semarang (studi pada anak jalanan lepas, anak pendampingan RPSA X, dan anak PGOT Balai Rehabilitasi Sosial Y Kota Semarang). Jurnal Kesehatan Masyarakat (e-Journal), 4(4): 298-304 